\title{
Ethephon Foliar Sprays Are Influenced by Carrier Water Alkalinity and Ambient Air Temperature at Application
}

\author{
Kellie J. Walters and Roberto G. Lopez ${ }^{1}$ \\ Department of Horticulture, Michigan State University, East Lansing, MI \\ 48824
}

Additional index words. bedding plants, calcium carbonate, ethylene, PGR, water quality

\begin{abstract}
The plant growth regulator (PGR) ethephon [(2-chloroethyl) phosphonic acid; ETH] can be sprayed on floriculture crops to inhibit internode elongation, hinder apical dominance, increase lateral branching, and abort flower buds and flowers. However, the efficacy of ETH can be reduced as the pH of the carrier water used to mix the spray solution or temperature increase. Therefore, our objective was to quantify how the efficacy of ethephon sprays is influenced by carrier water alkalinity $\left(\mathrm{CaCO}_{3} ; \mathrm{ALK}\right)$ and the air temperature at application (TEMP). Young plants of verbena (Verbena peruviana) 'Aztec Blue Velvet', ivy geranium (Pelargonium $\times$ peltatum) 'Precision Pink', and petunia (Petunia $\times$ hybrida) 'Easy Wave Neon Rose' were transplanted into $11-\mathrm{cm}$ diameter containers and grown in a greenhouse with an average daily air temperature (ADT) set point of $21^{\circ} \mathrm{C}$. Before the ETH spray application(s), the ADT in each greenhouse compartment was changed from a set point of $21^{\circ} \mathrm{C}$ to $14,17,20,23$, or $26^{\circ} \mathrm{C}$ for $\approx 24$ hours. Plants were sprayed with $0,250,500$, or $750 \mathrm{mg} \cdot \mathrm{L}^{-1} \mathrm{ETH}$ mixed with carrier water containing $\approx 50,150$, or $300 \mathrm{mg} \cdot \mathrm{L}^{-1} \mathrm{CaCO}_{3} 2$ and 3 weeks (Expt. 1) or 1 or 2 weeks (Expt. 2) after transplant. Generally, high ALK had a negative effect on spray efficacy. For example, an increase in $\mathrm{ALK}$ from 50 to $300 \mathrm{mg} \cdot \mathrm{L}^{-1} \mathrm{CaCO}_{3}$ resulted in one and five fewer ivy geranium and verbena branches, respectively. In addition, as application TEMP increased above $23^{\circ} \mathrm{C}$, chemical efficacy generally decreased in all species. For instance, as ETH increased from 0 to $750 \mathrm{mg} \cdot \mathrm{L}^{-1}$ across ALKs, inflorescence number of ivy geraniums increased from 7 to 18 at a TEMP of $23{ }^{\circ} \mathrm{C}$, but was unaffected at $26^{\circ} \mathrm{C}$. Based on our results, we can conclude that both ALK and TEMP influence ETH efficacy and are additional factors for greenhouse growers to consider when making applications.
\end{abstract}

A common production challenge for greenhouse producers of floriculture crops is excessive stem elongation and/or poor branching that leads to unmarketable plants and reduced profits. To increase plant densities, meet market or buyer height specifications for shipping, and produce compact, well-branched, and aesthetically appealing plants, greenhouse growers use a wide vari-

Received for publication 30 July 2018. Accepted for publication 21 Sept. 2018.

This work was supported by the U.S. Department of Agriculture National Institute of Food and Agriculture, Hatch project MICL02472.

We gratefully acknowledge support by the U.S. Department of Agriculture-Agricultural Research Service Floriculture and Nursery Research Initiative, Fine Americas, Inc., The Western Michigan Greenhouse Association, and the Metro Detroit Flower Growers Association for funding; Ball Horticultural Co. for plant material; The Blackmore Company for fertilizer; and Nathan DuRussel for technical assistance.

The use of trade names in this publication does not imply endorsement by Michigan State University of products named nor criticism of similar ones not mentioned.

${ }^{1}$ Corresponding author. E-mail: rglopez@msu.edu. ety of chemical plant growth regulators or retardants (PGRs) (Blanchard and Runkle, 2007; Currey et al., 2016a). The most commonly used PGRs are gibberellin inhibitors that control extension growth by inhibiting various steps in the gibberellin biosynthetic pathway (Rademacher, 2000). Although the PGR ethephon [(2-chloroethyl) phosphonic acid; ETH] is not a gibberellin inhibitor, it has been reported to influence the production of gibberellins (Furukawa et al., 1997).

Ethephon breaks down to release the plant hormone ethylene $\left(\mathrm{C}_{2} \mathrm{H}_{4}\right)$ as well as chlorine $\left(\mathrm{Cl}^{-}\right)$, and hydrogen phosphate $\left(\mathrm{H}_{2} \mathrm{PO}_{4}^{-}\right)$ (Biddle et al., 1976). It is labeled for foliar spray applications on floriculture crops to increase lateral branching, abort flowers and flower buds, and inhibit internode elongation (Currey et al., 2016b; Hayashi et al., 2001); although not labeled, recent research has shown that it can be effective as a substrate drench (Currey et al., 2016b; Miller et al., 2012). The increase in lateral branching is due to an inhibition of apical dominance (Andersen, 1976), and the control of flowering is due to ethylene-induced flower and flower bud abscission (Roberts et al., 1984). Ethylene also causes a rearrangement of the microfibrils in cell walls, resulting in a reduction of extension growth and increased stem diameter (Ridge, 1973). In addition, high ethephon concentrations can inhibit root growth and development (Feldman, 1984).

Before spray applications, the liquid ethephon is mixed with water, known as carrier water, to form the spray solution. The evolution of the liquid ethephon to the gaseous and active compound, ethylene, is hypothesized to influence the efficacy of foliar sprays due to the changing duration of exposure and concentration of ethylene surrounding and absorbed by the plant. However, this evolution and, therefore, the efficacy of ethephon applications can be influenced by a variety of factors, including temperature and spray solution pH (Klein et al., 1979; McReynolds and Kossuth, 1985).

Carrier water quality, specifically $\mathrm{pH}$ and alkalinity or the presence of calcium $(\mathrm{Ca})$ and magnesium $(\mathrm{Mg})$, is known to affect the efficacy of many agricultural chemicals, including weak acid herbicides (Chahal et al., 2012), insecticides, and miticides (Cloyd, 2007). For example, Mueller et al. (2006) found that glyphosate activity was less in solutions with $>250 \mathrm{mg} \cdot \mathrm{L}^{-1} \mathrm{Ca}$ and $\mathrm{Mg}$. Calcium and $\mathrm{Mg}$ cations have also been reported to lessen the activity of 2,4-dichlorophenoxyacetic acid (2,4-D) and dicamba (Nalewaja and Matysiak, 1993). In addition, water $\mathrm{pH}>7.0$ can cause weak acid herbicides, such as glyphosate, 2,4-D, and dicamba, to become negatively charged, thus inhibiting absorption by the leaf cuticle and cell membrane (Chahal et al., 2012). Carrier water, particularly its alkalinity and $\mathrm{pH}$, also can play a role in the chemical composition and evolution of PGRs, thus influencing efficacy (Camberato et al., 2014; Hammer, 2001).

The evolution of ethephon to ethylene increases as the spray solution $\mathrm{pH}$ increases above 4.5 (Klein et al., 1979; Warner and Leopold, 1969). The rapid release of ethylene from solution results in a phase change from liquid to gas, reducing the ethylene influx through stomata, and thus reducing chemical efficacy. Camberato et al. (2014) classified ethephon as a strong acid and reported that the addition of $500 \mathrm{mg} \cdot \mathrm{L}^{-1}$ ethephon [Collate ${ }^{\circledR}$ $(21.7 \%$ a.i.); Fine Americas, Inc., Walnut Creek, CA] to reverse osmosis carrier water with a $\mathrm{pH}$ of 5.3 or 8.2 , resulted in a final spray solution $\mathrm{pH}$ of 2.4 and 2.5 , respectively. However, the reduction in final solution $\mathrm{pH}$ was minimal when the solution was dilute and the carrier water had a high alkalinity. For example, when carrier water with $293 \mathrm{mg} \cdot \mathrm{L}^{-1}$ $\mathrm{CaCO}_{3}$ and $\mathrm{pH}$ of 7.3 was mixed with 250 and $750 \mathrm{mg} \cdot \mathrm{L}^{-1}$ ethephon, the final solution $\mathrm{pH}$ was 6.4 and 3.8, respectively.

Groundwater wells are a common greenhouse water source for irrigation and chemical mixing in the United States (Biernbaum, 1994). In the United States, $\approx 60 \%$ of groundwater sampled by DeSimone et al. (2015) used for drinking water had a high alkalinity, containing $120 \mathrm{mg} \cdot \mathrm{L}^{-1}$ or higher $\mathrm{CaCO}_{3}$, whereas only $20 \%$ contained $<60 \mathrm{mg} \cdot \mathrm{L}^{-1} \mathrm{CaCO}_{3}$. Groundwater containing high carbonate concentrations is largely due to carbonate-rock aquifers, 
particularly limestone aquifers, releasing compounds such as $\mathrm{CaCO}_{3}$ as rocks dissolve (DeSimone et al., 2015). Of the top 15 floriculture-producing states, Florida, Illinois, Michigan, Ohio, Texas, and Southern California (USDA, 2016) are in regions with high-alkalinity water (Briggs and Ficke, 1977; DeSimone et al., 2015).

Air temperature also influences the efficacy of many agricultural chemicals, including herbicides (Ganie et al., 2017), insecticides (Longstaff, 1988), and PGRs (Biddle et al., 1976). For example, herbicide efficacy generally increases as temperature increases for chemicals that are quickly metabolized (Ganie et al., 2017). Glyphosate efficacy is greater when applied at $35{ }^{\circ} \mathrm{C}$ compared with applications at $24{ }^{\circ} \mathrm{C}$ (McWhorter et al., 1980), whereas more slowly metabolized herbicides, such as mesotrione, have a greater efficacy when applied at lower temperatures (e.g., $25 / 15{ }^{\circ} \mathrm{C}$ compared with $40 / 30{ }^{\circ} \mathrm{C}$ day/night) (Godar et al., 2015). At high temperatures, the half-life of ethephon is less due to the rapid evolution from ethephon to ethylene (Biddle et al., 1976; Klein et al., 1979; Lougheed and Franklin, 1972). However, we have found no research conducted in a greenhouse environment to determine how average daily air temperature (ADT) during and following application (TEMP) affects the efficacy of ethephon on bedding plants.

We hypothesize that a high rate of evolution from ethephon to ethylene influences the efficacy of ethephon sprays. Rapid evolution due to high carrier water $\mathrm{CaCO}_{3}$ (ALK) when carrier water $\mathrm{pH}$ is high, as well as a high TEMP, will theoretically reduce ethephon spray efficacy. Therefore, our objectives were to determine how the efficacy of foliar ethephon sprays applied to aggressive bedding plant species is influenced by ALK and TEMP.

\section{Materials and Methods}

Plant material. Cuttings of verbena (Verbena peruviana) 'Aztec Blue Velvet' were stuck in 102-cell liner trays, and ivy geranium (Pelargonium $\times$ peltatum) 'Precision
Pink' were stuck in 104-cell liner trays, whereas petunias (Petunia $\times$ hybrida) 'Easy Wave Neon Rose' were sown in 288-cell plug trays by commercial propagators (Tagawa Greenhouses, Inc., Brighton, CO, or Dickman Farms, Auburn, NY). On receipt, on 12 Oct. 2016 (Expt. 1, all species), 14 Dec. 2016 (Expt. 2, petunia and verbena), or 21 Dec. 2016 (Expt. 2, ivy geranium), rooted liners and plugs were transplanted into round, $11-\mathrm{cm}$-diameter $(600-\mathrm{mL})$ containers filled with a $70 \%$ peatmoss, $21 \%$ perlite, and $9 \%$ vermiculite substrate mixture (Suremix; Michigan Grower Products, Inc., Galesburg, MI). Plants were irrigated as needed with reverse osmosis water supplemented with $13 \mathrm{~N}-3 \mathrm{P}-15 \mathrm{~K}$ water-soluble fertilizer providing (in $\mathrm{mg} \cdot \mathrm{L}^{-1}$ ) 125 nitrogen, 12 phosphorus, 100 potassium, $65 \mathrm{Ca}, 12 \mathrm{Mg}, 1.0$ iron and copper, 0.5 manganese and zinc, 0.3 boron, and 0.1 molybdenum (MSU Orchid RO Water Special; GreenCare Fertilizers, Inc., Kankakee, IL).

Greenhouse environment. Plants were grown in connecting glass-glazed greenhouse compartments with an ADT and vapor pressure deficit set point of $21{ }^{\circ} \mathrm{C}$ and $0.70 \mathrm{kPa}$, respectively. The photoperiod was $16 \mathrm{~h}(0600$ to $2200 \mathrm{HR}$ ) consisting of natural photoperiods (lat. $43^{\circ} \mathrm{N}$ ) and day-extension lighting from high-pressure sodium lamps that provided a supplemental photosynthetic photon flux density of $77 \pm 13 \mu \mathrm{mol} \cdot \mathrm{m}^{-2} \cdot \mathrm{s}^{-1}$ when the outdoor light intensity was below $\approx 440$ $\mu \mathrm{mol} \cdot \mathrm{m}^{-2} \cdot \mathrm{s}^{-1}$. Exhaust fans, evaporativepad cooling, radiant steam heating, and supplemental lighting were controlled by an environmental control system (Integro 725; Priva North America, Vineland Station, $\mathrm{ON}$, Canada). In each greenhouse compartment, a shielded and aspirated $0.13-\mathrm{mm}$ type E thermocouple (Omega Engineering, Stamford, CT) recorded the air temperature, and a quantum sensor (SQ-500-SS FullSpectrum Quantum Sensor; Apogee Instruments, Logan, UT) placed at canopy height recorded the light intensity. A CR-1000 datalogger (Campbell Scientific, Logan, UT) collected the environmental data every $15 \mathrm{~s}$ and hourly means were recorded. The mean daily light integrals \pm SD during Expts. 1 and 2 were $10.3 \pm 4.1 \mathrm{~mol} \cdot \mathrm{m}^{-2} \cdot \mathrm{d}^{-1}$ and $12.0 \pm 3.0$ $\mathrm{mol} \cdot \mathrm{m}^{-2} \cdot \mathrm{d}^{-1}$, and the mean ADTs \pm SD during Expts. 1 and 2 were $21.8 \pm 1.6{ }^{\circ} \mathrm{C}$ and $20.7 \pm$ $0.7^{\circ} \mathrm{C}$, respectively.

Ethephon treatments. Sulfuric acid (95\% to $98 \%, \mathrm{H}_{2} \mathrm{SO}_{4}$; J.T. Baker, Center Valley, PA) was added to well water to achieve target carrier water concentrations of $\approx 50,150$, or $300 \mathrm{mg} \cdot \mathrm{L}^{-1} \mathrm{CaCO}_{3}$ with actual concentrations reported in Table 1 , and a handheld colorimeter (HI775 Checker HC; Hanna Instruments, Woonsocket, RI) was used to determine the $\mathrm{CaCO}_{3}$ following a colorimetric reaction with an alkalinity reagent (HI775-26; Hanna Instruments). The adjusted well water was mixed with ethephon [Collate ${ }^{\circledR}$ (21.7\% a.i.), Fine Americas, Inc.] to create $0,250,500$, or $750 \mathrm{mg} \cdot \mathrm{L}^{-1}$ solutions (Table 1). PGR solution $\mathrm{pH}$ was measured with a portable $\mathrm{pH}$ meter [portable waterproof $\mathrm{pH} / \mathrm{ED} / \mathrm{TDS}$ meter (high range) HI991301; Hanna Instruments]. Solution pH and ALK were measured for each treatment and the means \pm SD are reported in Table 1.

Ethephon solutions were applied at a volume of $0.2 \mathrm{~L} \cdot \mathrm{m}^{-2}, 14$ and $21 \mathrm{~d}$ after transplant for Expt. 1, and 7 (verbena and ivy geranium) or $14 \mathrm{~d}$ (petunia) after transplant for Expt. 2 . Before the foliar ethephon spray applications were initiated, the ADT in each of the separate glass-glazed greenhouse compartments was changed from a constant set point of $21{ }^{\circ} \mathrm{C}$ to $14,17,20,23$, or $26^{\circ} \mathrm{C}$ for $\approx 24 \mathrm{~h}$ with actual temperatures reported in Table 2 . After $\approx 24 \mathrm{~h}$, the ADT was changed back to $21{ }^{\circ} \mathrm{C}$ for the remainder of the study.

Data collection and analysis. For both experiments, the date of first open flower was recorded, and length of the longest stem and branch number $(>2.5 \mathrm{~cm})$ was measured at first spray application and at first open flower. The stem length and branch number at the first spray application were subtracted from the stem length and branch number, respectively, at first open flower to determine the increase in stem length and branch number with these values being used for analysis and are henceforth referred to as "stem length" and "branch number." In Expt. 2, inflorescence number at first open flower was recorded for ivy geranium.

Table 1. The $\mathrm{pH}$ and alkalinity (ALK) of well water acidified to create $0,250,500$, and $750 \mathrm{mg} \cdot \mathrm{L}^{-1}$ ethephon spray solution concentrations (ETH) from carrier water with a target ALK of 50,150, or $300 \mathrm{mg} \cdot \mathrm{L}^{-1} \mathrm{CaCO}_{3}$, the $\mathrm{pH}$ and $\mathrm{ALK}$ of the carrier water, the ETH added, and the ALK and $\mathrm{pH}$ of the final spray solutions.

\begin{tabular}{|c|c|c|c|c|c|c|c|}
\hline \multicolumn{8}{|c|}{ Adjusted carrier water } \\
\hline $338 \pm 10$ & $7.3 \pm 0.2$ & 300 & $301 \pm 2$ & $7.3 \pm 0.2$ & 0 & $301 \pm 2$ & $7.3 \pm 0.2$ \\
\hline $338 \pm 10$ & $7.3 \pm 0.2$ & 300 & $301 \pm 2$ & $7.3 \pm 0.2$ & 500 & $85 \pm 11$ & $6.1 \pm 0.1$ \\
\hline $338 \pm 10$ & $7.3 \pm 0.2$ & 300 & $301 \pm 2$ & $7.3 \pm 0.2$ & 750 & $2 \pm 2$ & $3.6 \pm 0.2$ \\
\hline $338 \pm 10$ & $7.3 \pm 0.2$ & 150 & $151 \pm 1$ & $6.4 \pm 0.2$ & 0 & $151 \pm 1$ & $6.4 \pm 0.2$ \\
\hline $338 \pm 10$ & $7.3 \pm 0.2$ & 150 & $151 \pm 1$ & $6.4 \pm 0.2$ & 250 & $47 \pm 3$ & $5.8 \pm 0.1$ \\
\hline $338 \pm 10$ & $7.3 \pm 0.2$ & 50 & $52 \pm 1$ & $5.8 \pm 0.2$ & 0 & $51 \pm 1$ & $5.8 \pm 0.2$ \\
\hline $338 \pm 10$ & $7.3 \pm 0.2$ & 50 & $52 \pm 1$ & $5.8 \pm 0.2$ & 250 & $0 \pm 0$ & $3.3 \pm 0.1$ \\
\hline $338 \pm 10$ & $7.3 \pm 0.2$ & 50 & $52 \pm 1$ & $5.8 \pm 0.2$ & 500 & $0 \pm 0$ & $2.8 \pm 0.1$ \\
\hline $338 \pm 10$ & $7.3 \pm 0.2$ & 50 & $52 \pm 1$ & $5.8 \pm 0.2$ & 750 & $0 \pm 0$ & $0.6 \pm 0.2$ \\
\hline
\end{tabular}

Mean values reported are the average of four spray treatments across two experiments. 
The experiment was organized in a randomized complete-block design with a threeway factorial arrangement. Plants were blocked by TEMP (five levels), ALK (three levels), and ETH (four levels) with six plants per treatment combination and were randomized in a common greenhouse environment after PGR applications. The experiment was performed twice over time for the three species evaluated. Analysis of variance and Student's $t$ test were performed using JMP (version 12.0.1; SAS Institute, Inc., Cary, NC).

\section{Results}

Expt. 1. In Expt. 1, ETH $\times$ ALK, ETH×TEMP, and ALK $\times$ TEMP interacted to influence time to flower of ivy geranium, whereas only ETH $\times$ ALK and ETH $\times$ TEMP influenced time to flower of petunia (Table 3). For example, an increase in carrier water ALK (from 50 to $300 \mathrm{mg} \cdot \mathrm{L}^{-1} \mathrm{CaCO}_{3}$ ) hastened time to flower of ivy geranium and petunia by 5 and $11 \mathrm{~d}$, respectively, across TEMPs when ETH was sprayed at $250 \mathrm{mg} \cdot \mathrm{L}^{-1}$ (Fig. 1). Conversely, an increase in ALK (from 50 to $300 \mathrm{mg} \cdot \mathrm{L}^{-1}$ $\mathrm{CaCO}_{3}$ ) for petunia and ivy geranium sprayed with $750 \mathrm{mg} \cdot \mathrm{L}^{-1} \mathrm{ETH}$ delayed flowering at 5 and $0 \mathrm{~d}$, respectively. TEMP and ETH influenced time to flower for verbena, as plants sprayed at $14{ }^{\circ} \mathrm{C}$ flowered $5 \mathrm{~d}$ later than those sprayed at $26{ }^{\circ} \mathrm{C}$, and increasing ETH from 500 to $750 \mathrm{mg} \cdot \mathrm{L}^{-1}$ caused a 3 -d delay in flowering (Table 3; Fig. 1).

Branch number of ivy geranium at flowering was influenced by the interaction of $\mathrm{TEMP} \times \mathrm{ALK} \times \mathrm{ETH}$, whereas only TEMP and ETH influenced branch number of verbena (Table 3). For instance, as TEMP increased from 14 to $26{ }^{\circ} \mathrm{C}$, verbena branch number increased from 12 to 18 branches across ETH and ALK (Fig. 2).

Increase in stem length for ivy geranium and petunia was influenced by the interaction of TEMP $\times$ ALK $\times$ ETH (Table 3). Verbena was influenced by ALK $\times$ ETH and ETH $\times$ TEMP interactions. For example, increasing ALK (from 150 to $300 \mathrm{mg} \cdot \mathrm{L}^{-1}$ $\mathrm{CaCO}_{3}$ ) resulted in similar stem length when ETH was $250 \mathrm{mg} \cdot \mathrm{L}^{-1}$. However, when 750 $\mathrm{mg} \cdot \mathrm{L}^{-1}$ ETH was sprayed, the stem length was $1.2 \mathrm{~cm}$ shorter when the ALK was 150 than $300 \mathrm{mg} \cdot \mathrm{L}^{-1} \mathrm{CaCO}_{3}$ (Fig. 2). At a TEMP of $23{ }^{\circ} \mathrm{C}$, stem length of verbena at flowering was $4.0 \mathrm{~cm}$ longer when sprayed with 250 $\mathrm{mg} \cdot \mathrm{L}^{-1}$ ETH compared with $750 \mathrm{mg} \cdot \mathrm{L}^{-1} \mathrm{ETH}$ (Fig. 2). However, at a TEMP of $26^{\circ} \mathrm{C}$, stem length increased by only $1.8 \mathrm{~cm}$.

Expt. 2. Ivy geranium and verbena flowered 23 and $21 \mathrm{~d}$ later, respectively, as ETH increased from 0 to $750 \mathrm{mg} \cdot \mathrm{L}^{-1}$ at $23{ }^{\circ} \mathrm{C}$; however, there was no difference at $26{ }^{\circ} \mathrm{C}$ (Table 4; Fig. 3). Time to flower of verbena was influenced by the interaction of ETH $\times$ ALK (Table 4). For example, flowering of verbena was not delayed by increasing ETH from 500 to $750 \mathrm{mg} \cdot \mathrm{L}^{-1}$ at an $\mathrm{ALK}$ of $50 \mathrm{mg} \cdot \mathrm{L}^{-1} \mathrm{CaCO}_{3}$, whereas flowering was delayed by $7 \mathrm{~d}$ as ETH increased from 500 to $750 \mathrm{mg} \cdot \mathrm{L}^{-1}$ at an ALK of $300 \mathrm{mg} \cdot \mathrm{L}^{-1} \mathrm{CaCO}_{3}$.

Table 2. Average daily air temperature during and $24 \mathrm{~h}$ after spray application (TEMP) for two experiments and three spray applications.

\begin{tabular}{lccc}
\hline TEMP set point $\left({ }^{\circ} \mathrm{C}\right)$ & Expt. & Spray $($ no. $)$ & Actual TEMP $\left({ }^{\circ} \mathrm{C}\right)$ \\
\hline 14 & 1 & 1 & $16.1 \pm 1.6$ \\
& 1 & 2 & $17.3 \pm 1.6$ \\
17 & 2 & 1 & $14.3 \pm 1.0$ \\
& 1 & 1 & $20.0 \pm 1.0$ \\
20 & 1 & 2 & $20.3 \pm 1.1$ \\
& 2 & 1 & $17.3 \pm 1.0$ \\
23 & 1 & 1 & $21.0 \pm 0.6$ \\
& 1 & 2 & $24.2 \pm 3.4$ \\
26 & 2 & 1 & $20.2 \pm 0.9$ \\
& 1 & 2 & $24.6 \pm 0.7$ \\
& 1 & 1 & $25.0 \pm 1.5$ \\
& 2 & 1 & $23.1 \pm 1.2$ \\
& 1 & 2 & $27.0 \pm 0.8$ \\
& 1 & 1 & $26.9 \pm 0.7$ \\
\hline
\end{tabular}

Data were collected every $15 \mathrm{~s}$ with means logged every hour.

Table 3. Analysis of variance for ethephon spray solution concentration (ETH), carrier water alkalinity (ALK), and average daily air temperature at application (TEMP) effects on time to flower and increase in stem length and branch number at first open flower of ivy geranium, verbena, and petunia in Expt. 1.

\begin{tabular}{|c|c|c|c|}
\hline & Time to flower & Branch number at flowering & Stem length at flowering \\
\hline \multicolumn{4}{|c|}{ Ivy Geranium } \\
\hline ETH & $* * *$ & $* * *$ & * \\
\hline ALK & $*$ & ** & NS \\
\hline TEMP & $* * *$ & $* * *$ & * \\
\hline ETH*ALK & $* *$ & $*$ & * \\
\hline ETH*TEMP & $*$ & $* * *$ & NS \\
\hline ALK*TEMP & $* * *$ & NS & NS \\
\hline TEMP*ALK*ETH & NS & * & * \\
\hline \multicolumn{4}{|c|}{ Verbena } \\
\hline ETH & $* * *$ & ** & $* * *$ \\
\hline ALK & NS & NS & $* * *$ \\
\hline TEMP & $* * *$ & $* * *$ & $* * *$ \\
\hline ETH*ALK & NS & NS & ** \\
\hline ETH*TEMP & NS & NS & ** \\
\hline ALK*TEMP & NS & NS & NS \\
\hline TEMP*ALK*ETH & NS & NS & NS \\
\hline \multicolumn{4}{|c|}{ Petunia } \\
\hline ETH & $* * *$ & $-^{\mathrm{z}}$ & $* * *$ \\
\hline ALK & $* * *$ & - & $* * *$ \\
\hline TEMP & *** & - & $* * *$ \\
\hline ETH*ALK & $* * *$ & - & $* * *$ \\
\hline ETH*TEMP & $* *$ & - & ** \\
\hline ALK*TEMP & NS & - & NS \\
\hline TEMP*ALK*ETH & NS & - & \\
\hline
\end{tabular}

${ }^{\mathrm{z}}$ Data not collected.

Ns, *,**,***Nonsignificant or significant at $P \leq 0.05,0.01$, or 0.001 , respectively.

At $23{ }^{\circ} \mathrm{C}$, the number of ivy geranium, petunia, and verbena branches at first open flower increased from 5 to 11,38 to 94 , and 18 to 48 branches, respectively, as ETH increased from 0 to $750 \mathrm{mg} \cdot \mathrm{L}^{-1}$; however, no differences were observed at $26{ }^{\circ} \mathrm{C}$ (Table 4; Fig. 4). As ALK increased from 50 to $300 \mathrm{mg} \cdot \mathrm{L}^{-1} \mathrm{CaCO}_{3}$, ivy geranium and verbena had 1 and 5 fewer branches, respectively, regardless of ETH. At $17{ }^{\circ} \mathrm{C}$, petunia had 14 fewer branches as ALK increased from 50 to $300 \mathrm{mg} \cdot \mathrm{L}^{-1} \mathrm{CaCO}_{3}$; however, plants grown at $26^{\circ} \mathrm{C}$ had the same number of branches, regardless of ALK (Fig. 4).

Ivy geranium and verbena stem length was similar at a TEMP of $26{ }^{\circ} \mathrm{C}$ as ETH increased from 0 to $750 \mathrm{mg} \cdot \mathrm{L}^{-1}$; however, at $20{ }^{\circ} \mathrm{C}$, ivy geranium stem length was $2.9 \mathrm{~cm}$ shorter, and for verbena, was $4.6 \mathrm{~cm}$ longer as ETH increased from 0 to $750 \mathrm{mg} \cdot \mathrm{L}^{-1}$ (Table 4; Fig. 4). In addition, stem length of ivy geranium and verbena were 1.7 and 0.9 $\mathrm{cm}$ less, respectively, as ALK increased from 50 to $300 \mathrm{mg} \cdot \mathrm{L}^{-1} \mathrm{CaCO}_{3}$. Similar to other growth and developmental parameters, petunia stem length was unaffected by ALK at a TEMP of $26^{\circ} \mathrm{C}$ (Fig. 4).

At a TEMP of $26{ }^{\circ} \mathrm{C}$, ivy geranium inflorescence number was similar as ETH increased from 0 to $750 \mathrm{mg} \cdot \mathrm{L}^{-1}$, but was different at TEMPs $\leq 23{ }^{\circ} \mathrm{C}$ (Table 4; Fig. 3). For example, at $23{ }^{\circ} \mathrm{C}$ ivy geranium inflorescence number increased from 7 to 18 as ETH increased from 0 to $750 \mathrm{mg} \cdot \mathrm{L}^{-1}$.

\section{Discussion}

Increasing the ETH in spray solutions can help enhance plant responses to ethephon in two ways. First, there is an increase in the active ingredient, ethephon, and greater ethylene release resulting in more robust plant responses (Currey et al., 2016b). Second, 


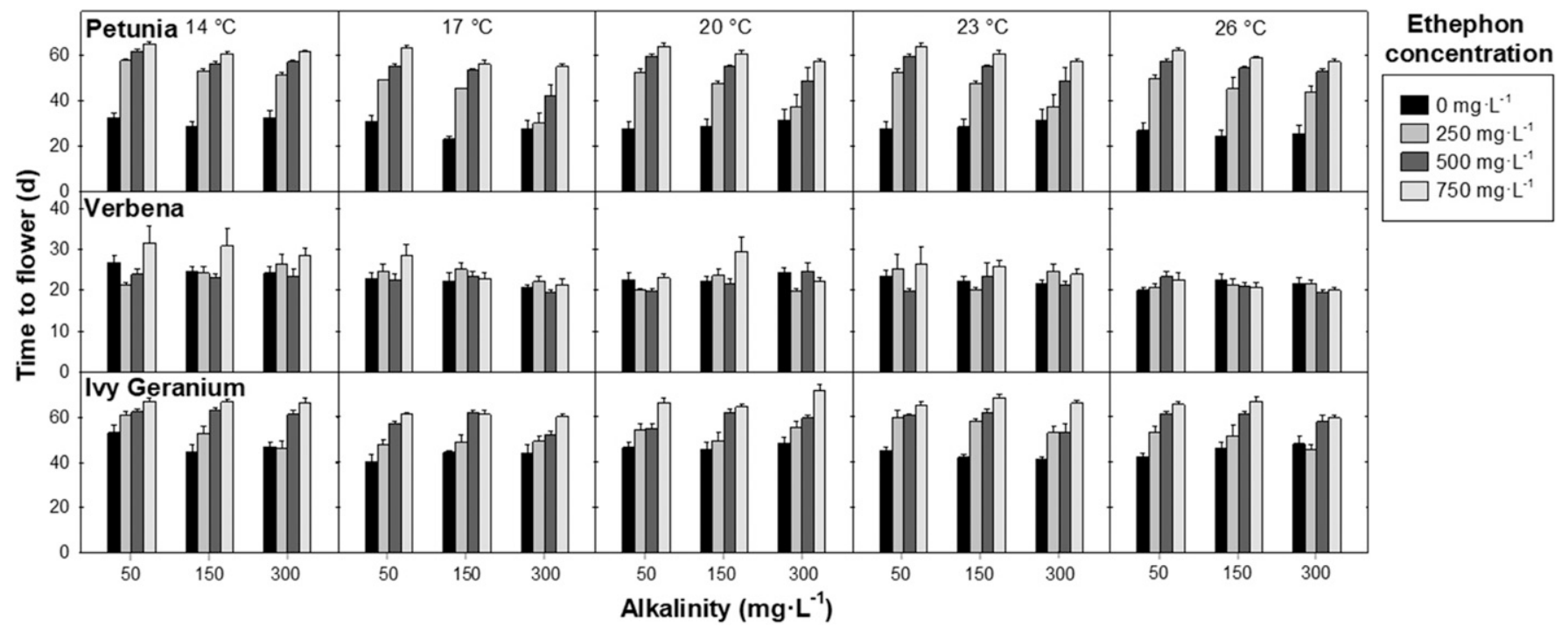

Fig. 1. Time to flower for petunia, verbena, and ivy geranium sprayed with $0,250,500$, or $750 \mathrm{mg} \cdot \mathrm{L}^{-1}$ ethephon concentrations (ETH), with carrier water alkalinities of 50,150 , or $300 \mathrm{mg} \cdot \mathrm{L}^{-1} \mathrm{CaCO}_{3}$, and target average daily air temperatures at application of $14,17,20,23$, or $26^{\circ} \mathrm{C}$ in Expt. 1 . Each bar represents a mean of six plants, and error bars represent SE.

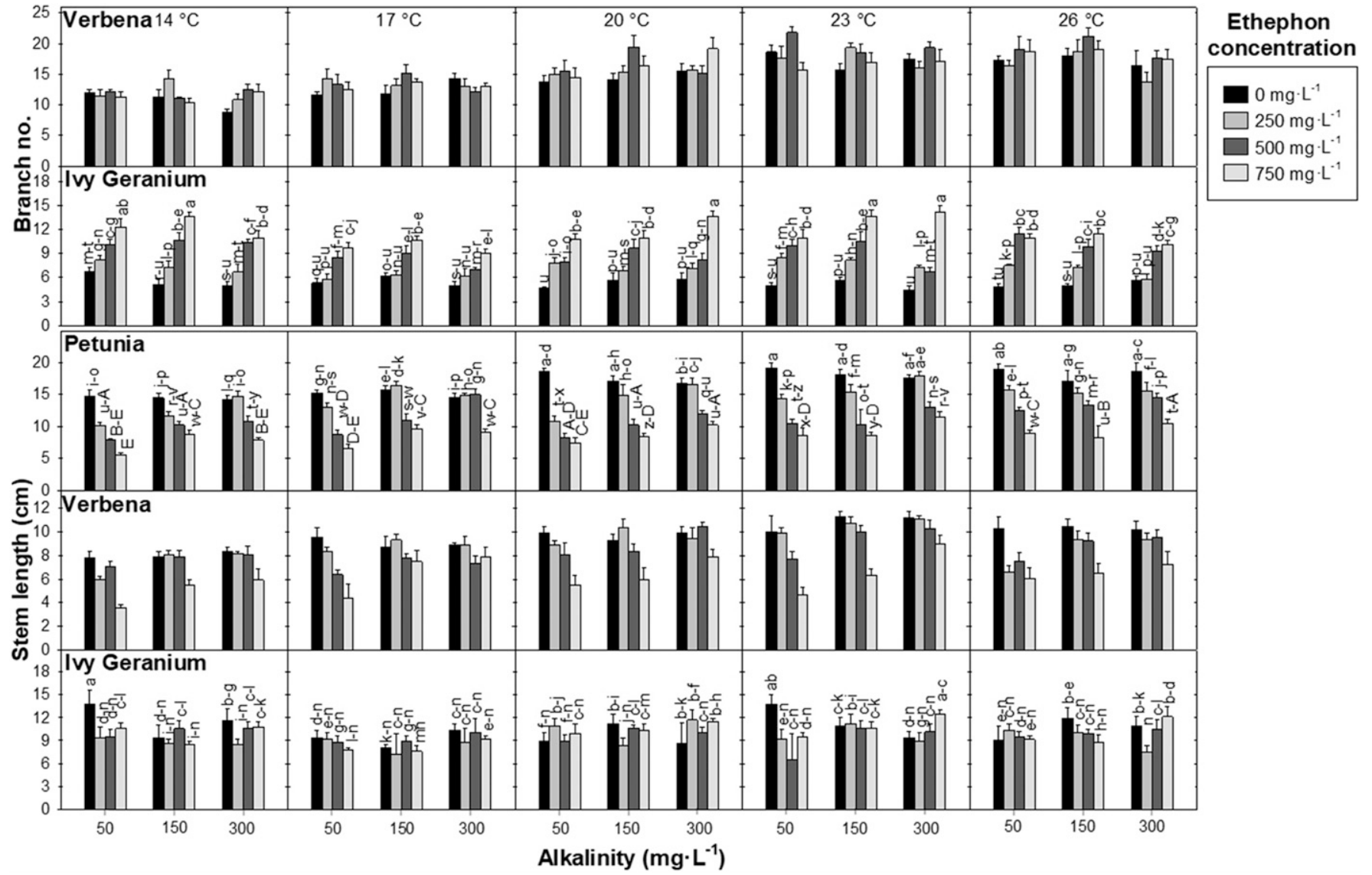

Fig. 2. Increase in branch number and stem length from application to first open flower for verbena and ivy geranium and increase in stem length from application to first open flower for petunia sprayed with $0,250,500$, or $750 \mathrm{mg} \cdot \mathrm{L}^{-1}$ ethephon concentrations $(\mathrm{ETH})$, with carrier water alkalinities (ALKs) of 50, 150 , or $300 \mathrm{mg} \cdot \mathrm{L}^{-1}$, and target average daily temperatures at application (TEMPs) of 14, 17, 20, 23, or $26{ }^{\circ} \mathrm{C}$ in Expt. 1. Letters indicate mean separation across TEMPs, ALKs, and ETHs by Student's $t$ test at $P \leq 0.05$ within a species. Each bar represents a mean of six plants, and error bars represent sE.

ethephon is a strong acid; therefore, increasing ETH also results in a lower spray solution $\mathrm{pH}$ (Camberato et al., 2014). Moreover, because the rate of ethephon conversion into ethylene increases as $\mathrm{pH}$ increases (Klein et al., 1979; Warner and Leopold, 1969) and the prolonged ethephon release of ethylene is hypothesized to increase efficacy, ETH influences plant responses, as our results confirm (Table 1).

In Expt. 1, nearly all crops and growth parameters were influenced by the interaction of ETH $\times$ ALK, where differences in ALK effects are more pronounced when lower ETH was used (Table 3). To illustrate, ivy geranium and petunia flowering was delayed to a greater extent as the ALK of a $250 \mathrm{mg} \cdot \mathrm{L}^{-1}$ ETH solution increased from 50 to $300 \mathrm{mg} \cdot \mathrm{L}^{-1}$ 


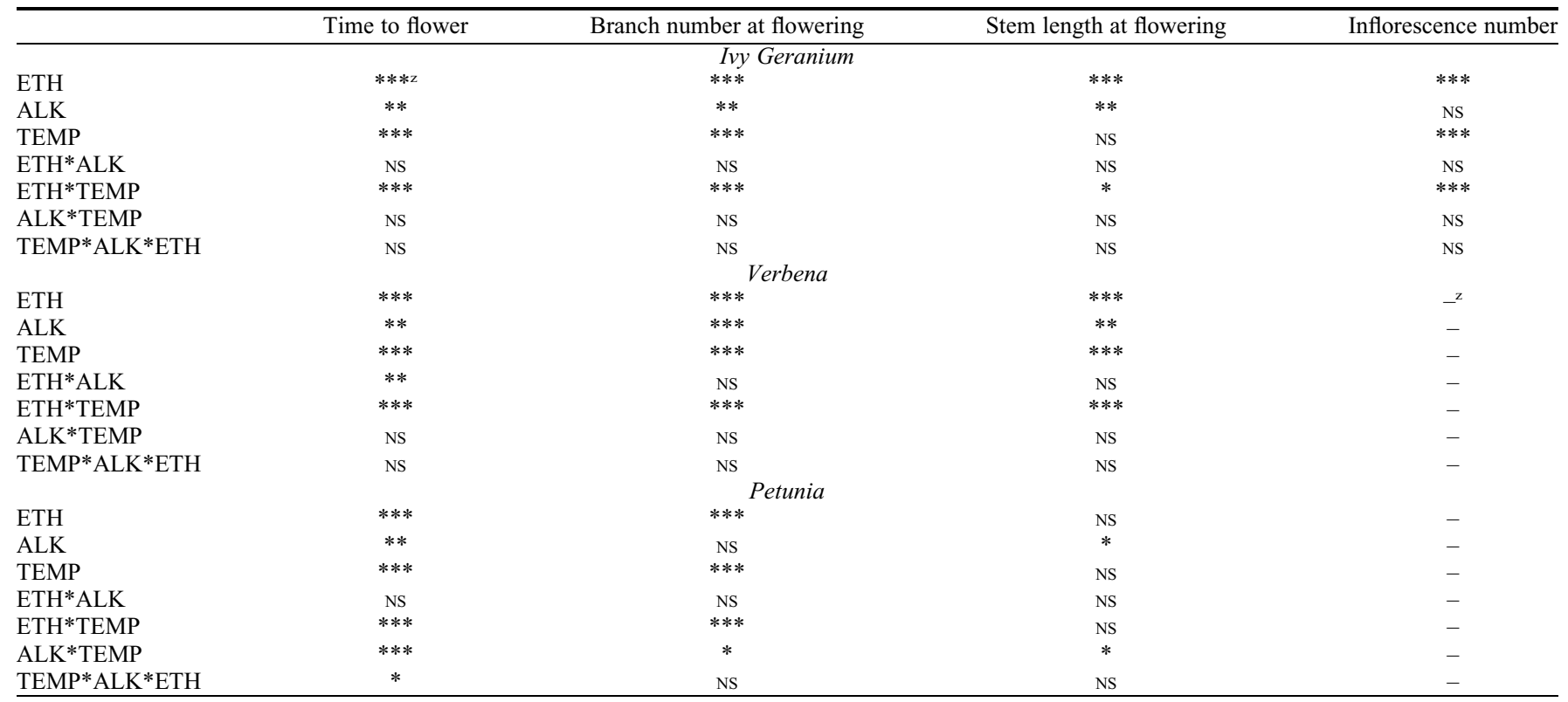

$\mathrm{z}$ Data not collected.

Ns, *,*****Nonsignificant or significant at $P \leq 0.05,0.01$, or 0.001 , respectively.

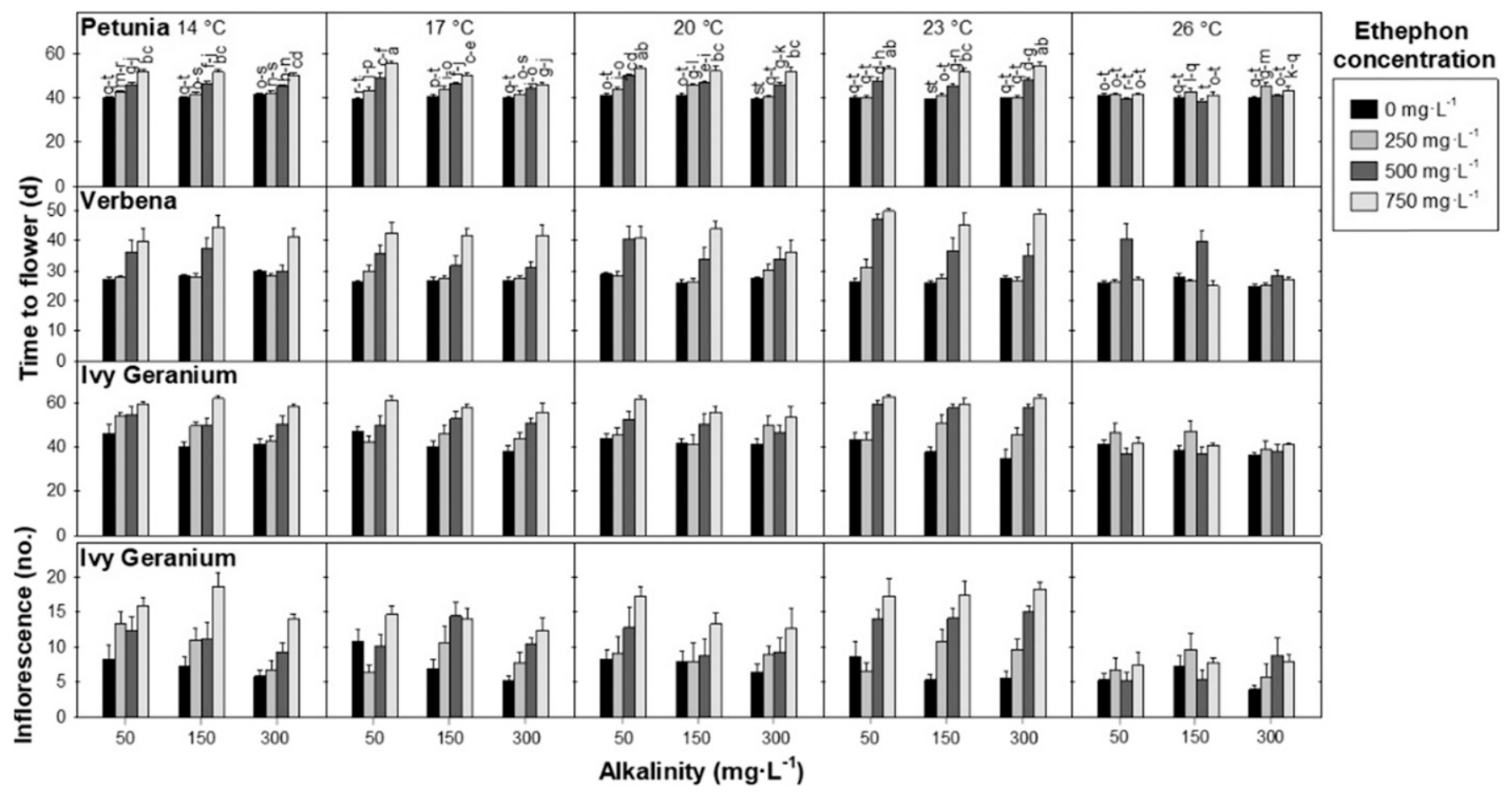

Fig. 3. Time to flower for petunia, verbena, and ivy geranium and inflorescence number at first open flower of ivy geranium sprayed with 0 , 250, 500 , or $750 \mathrm{mg} \cdot \mathrm{L}^{-1}$ ethephon concentrations (ETH), with carrier water alkalinities (ALKs) of 50,150 , or $300 \mathrm{mg} \cdot \mathrm{L}^{-1} \mathrm{CaCO}_{3}$, and target average daily air temperatures at application (TEMPs) of 14, 17, 20,23, or $26^{\circ} \mathrm{C}$ in Expt. 2. Letters indicate mean separation across TEMPs, ALKs, and ETHs by Student's $t$ test at $P \leq 0.05$ within a species. Each bar represents a mean of six plants, and error bars represent SE.

$\mathrm{CaCO}_{3}$, than at an $\mathrm{ETH}$ of $750 \mathrm{mg} \cdot \mathrm{L}^{-1}$ where there were slight to no differences in days to flower between ALKs. This may be due to the differences in solution $\mathrm{pH}$. When ALK is high, low ETH does not neutralize carrier water $\mathrm{pH}$ as much as high ETH (Table 1). However, when the ALK is low, lower ETH results in a greater reduction in solution $\mathrm{pH}$. This may be why there was less difference among ALKs when high ETH was sprayed, but there were greater differences when lower ETH was sprayed.

In Expt. 2, ivy geranium and verbena were influenced by ALK, but generally not the interaction of ALK and either TEMP or ETH (Table 4). In contrast, petunia was influenced by the interaction of ALK $\times$ TEMP. In most cases, as ALK increased from 50 to 300 $\mathrm{mg} \cdot \mathrm{L}^{-1} \mathrm{CaCO}_{3}$, branch number and days to flower were less, whereas stem length at flowering increased (Figs. 3 and 4). Differences between species may be due to a variety of factors, including epicuticular wax (Beaudry and Kays, 1987), pubescence affecting airflow around the leaf, stomatal characteristics including whether the plant has amphi- or hemistomatous leaves (Beaudry and 


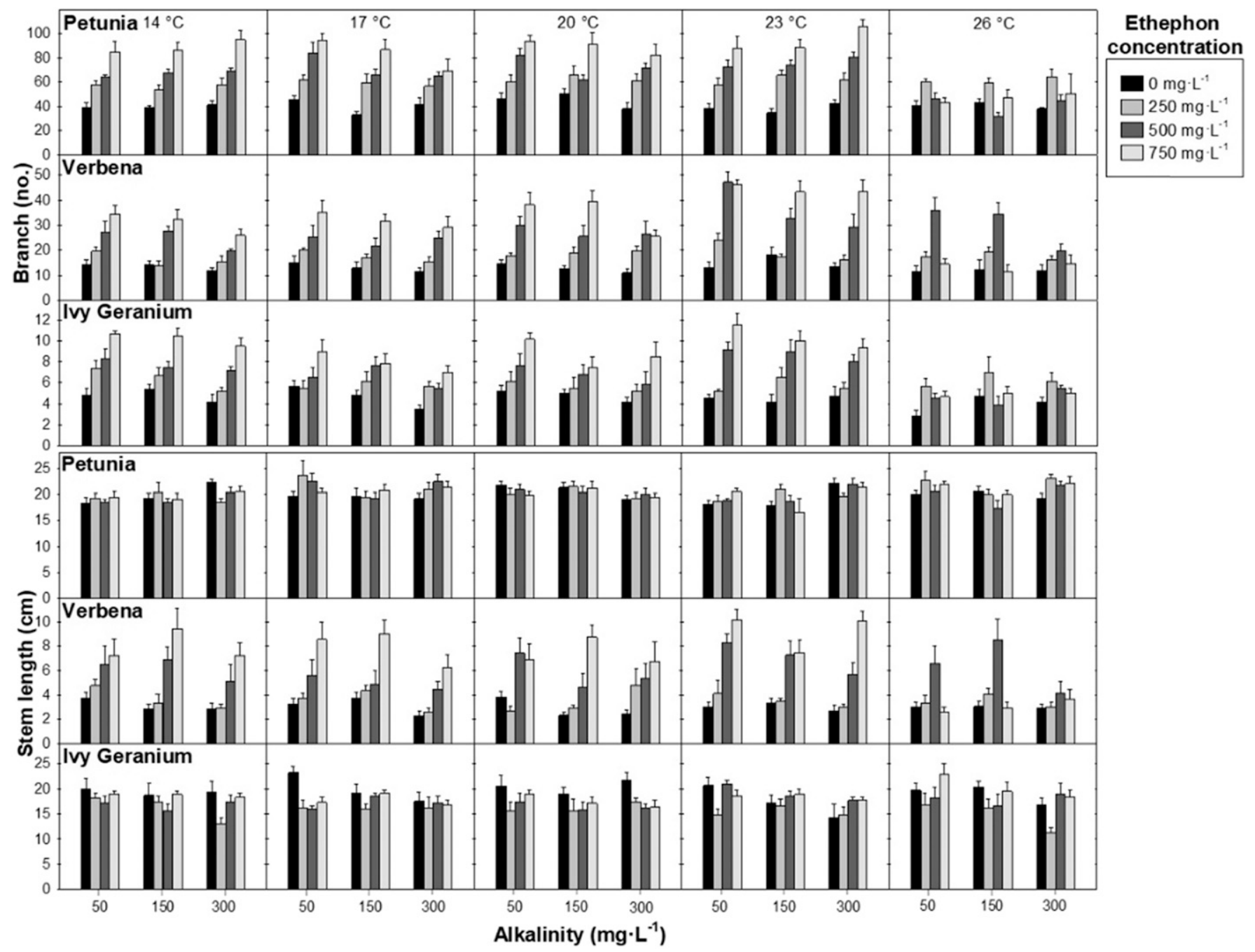

Fig. 4. Increase in branch number and stem length from application to first open flower for petunia, verbena, and ivy geranium sprayed with 0 , 250, 500, or $750 \mathrm{mg} \cdot \mathrm{L}^{-1}$ ethephon concentrations, with carrier water alkalinities of 50,150 , or $300 \mathrm{mg} \cdot \mathrm{L}^{-1} \mathrm{CaCO}_{3}$, and target average daily temperatures at application of $14,17,20,23$, or $26^{\circ} \mathrm{C}$ in Expt. 2. Each bar represents a mean of six plants, and error bars represent SE.

Kays, 1988), and the presence of gibberellin (Furukawa et al., 1997). Higher concentrations of epicuticular wax result in a lower rate of ethephon evolution to ethylene (Beaudry and Kays, 1987). As airflow increases, ethephon or ethylene is more likely to be carried away from the leaf before the compound can enter the stomata into the leaf tissue (Beaudry and Kays, 1988). Because ethephon sprays are applied to the adaxial leaf surface, whether plants have stomata on only the abaxial (hemistomatous) or both abaxial and adaxial surface (amphistomatous) can affect ethylene flux (Beaudry and Kays, 1988).

Generally, stem elongation was less as ETH increased and ALK decreased. This is because of ethylene affecting cell expansion in two ways: by decreasing the overall rate of expansion (Ridge and Osborne, 1969), and by changing the directionality of growth (Ridge, 1973). Turgor pressure exerts outwarddirected force in equal directions on the cell wall. Directionality of cell expansion is determined by cellulose microfibril orientation within the cell wall. Newly formed cells in the center of the meristem contain isodiametricoriented microfibrils resulting in a round cell.
However, as the cells mature, microfibrils are most commonly aligned transversely to promote anisotropic growth and an increase in length more than width (Baskin, 2005). Ethylene causes a rearrangement of the microfibrils in cell walls of the plant from transverse to longitudinal causing lateral cell expansion, less in stem elongation, and an increased stem diameter (Ridge, 1973). However, verbena in Expt. 2 had the opposite response. Researchers have found that in some plants, including rice (Oryza sativa; Furukawa et al., 1997), celeryleaved buttercup (Ranunculus sceleratus; Musgrave and Walters, 1973), water starwort (Callitriche platycarpa; Musgrave et al., 1972), and marsh and curly dock (Rumex palustris and Rumex crispus; Voesenek and Blom, 1989), ethylene can cause elongation especially when under water stress (Bleecker and Kende, 2000). This phenomenon may be influenced by gibberellins and may be species dependent (Furukawa et al., 1997).

Air temperature at application did not have the same effect between Expt. 1 and Expt. 2 (Tables 3 and 4). This may be due to the differences in experimental design. In Expt. 1, plants were sprayed twice and exposed to TEMP treatments for a total of $\approx 96$ h compared with only $\approx 24$ h for plants in Expt. 2. The differences in days to flower, for instance, between experiments may be due to differences in ADT influencing growth and development in addition to the TEMP affecting spray efficacy. For example, time to flower of verbena in Expt. 1 was hastened by $5 \mathrm{~d}$ when the TEMP was $26^{\circ} \mathrm{C}$ compared with $14{ }^{\circ} \mathrm{C}$ (Fig. 1). Similarly, Kaczperski et al. (1991) reported that flowering of petunia 'Snow Cloud' was hastened as temperature increased from 10 to $30^{\circ} \mathrm{C}$ and Moccaldi and Runkle (2007) reported that as temperatures increased from 14 to $27^{\circ} \mathrm{C}$, the rate of development of salvia (Salvia splendens) 'Vista Red' and marigold (Tagetes patula) 'Bonanza Yellow' increased.

In Expt. 2, plants sprayed at TEMPs between 14 and $23{ }^{\circ} \mathrm{C}$ generally had responses similar to the ETH and ALK treatments; however, the responses of plants sprayed at TEMPs of $26{ }^{\circ} \mathrm{C}$ more closely resembled those sprayed with $0 \mathrm{mg} \cdot \mathrm{L}^{-1} \mathrm{ETH}$ (Figs. 3 and 4). This may be because of the short half-life of ethephon owing to the rapid evolution from ethephon to ethylene at $26^{\circ} \mathrm{C}$ 
(Biddle et al., 1976; Klein et al., 1979; Lougheed and Franklin, 1972). Klein et al. (1979) demonstrated that the half-life of ethephon decomposition decreases dramatically regardless of $\mathrm{pH}$ or vapor pressure as temperature increases from 20 to $30^{\circ} \mathrm{C}$. This also supports the idea that the interactions of ETH $\times$ TEMP and ALK $\times$ TEMP are largely attributed to the difference at high TEMP, meaning that at higher TEMP, the evolution is rapid and results in reduced spray efficacy regardless of solution $\mathrm{pH}$.

\section{Conclusions}

To have the greatest ethephon efficacy, sprays should be applied when greenhouse TEMPs are $\leq 23{ }^{\circ} \mathrm{C}$. High ETH is not influenced by ALK as much as low ETH. Therefore, reducing ALK will have the greatest increase in spray efficacy when low ETH (250 $\mathrm{mg} \cdot \mathrm{L}^{-1}$ ) is being sprayed; however, there is still a benefit to decreasing ALK of the carrier water of high-ETH sprays.

\section{Literature Cited}

Andersen, A.S. 1976. Regulation of apical dominance by ethephon, irradiance and $\mathrm{CO}_{2}$. Physiol. Plant. 37(4):303-308.

Baskin, T.I. 2005. Anisotropic expansion of the plant cell wall. Annu. Rev. Cell Dev. Biol. 21:203-222.

Beaudry, R.M. and S.J. Kays. 1987. Effects of physical and environmental factors on the release kinetics of ethylene from (2-chloroethyl) phosponic acid and (2-chloroethyl)-methylbis (phenylmethoxy)saline. J. Amer. Soc. Hort. Sci. 114:352-359.

Beaudry, R.M. and S.J. Kays. 1988. Flux of ethylene from leaves treated with a polar or non-polar ethylene-releasing compound. J. Amer. Soc. Hort. Sci. 113:784-789.

Biddle, E., D.G. Kerfoot, Y.H. Kho, and K.E. Russell. 1976. Kinetic studies of the thermal decomposition of 2-chloroethylphosphonic acid in aqueous solution. Plant Physiol. 58(5):700-702.

Biernbaum, J. 1994. Water quality, p. 65-76. In: H.K. Tayama, T.J. Roll, and M.L Gatson (eds.). Tips on growing bedding plants. 3rd ed. O.F.A. Serv., Inc, Columbus, OH.

Blanchard, M.G. and E.S. Runkle. 2007. Dipping bedding plant liners in paclobutrazol or uniconazole inhibits subsequent stem extension. HortTechnology 17:178-182.

Bleecker, A.B. and H. Kende. 2000. Ethylene: A gaseous signal molecule in plants. Annu. Rev. Cell Dev. Biol. 16(1):1-18.

Briggs, J.C. and J.F. Ficke. 1977. Quality of rivers of the United States, 1975 water year; based on the National Stream Quality Accounting Network (NASQAN) (No. 78-200). U.S. Geological Survey, Reston, VA.
Camberato, D.M., J.J. Camberato, and R.G. Lopez. 2014. Determining the effect of carrier water $\mathrm{pH}$ and bicarbonate concentration on final $\mathrm{pH}$ of plant growth regulator solutions. HortScience 49:1176-1182.

Chahal, G., J. Roskamp, T. Legleiter, and B. Johnson. 2012. The influence of spray water quality on herbicide efficacy. <https://ag.purdue.edu/btny/ weedscience/documents/Water_Quality.pdf $>$.

Cloyd, R.A. 2007. Effects of $\mathrm{pH}$ on insecticides and miticides, p. 9-11. In: R.A. Cloyd. Plant protection: Managing greenhouse insect and mite pests. Ball Publishing, Batavia, IL.

Currey, C.J., K.J. Walters, and K.G. McCabe. 2016a. Quantifying growth control of lantana cultivars varying in vigor with ancymidol, flurprimidol, paclobutrazol, and uniconazole substrate drenches. HortTechnology 26:320-326.

Currey, C.J., K.G. McCabe, and K.J. Walters 2016b. Concentration and timing of ethephon drench applications interact to affect growth and flowering of containerized angelonia and geranium. HortScience 51:1542-1546.

DeSimone, L.A., P.B. McMahon, and M.R. Rosen. 2015. The quality of our nation's waters: Water quality in principal aquifers of the United States, 1991-2010 (No. 1360). U.S. Geological Survey, Reston, VA.

Feldman, L.J. 1984. Regulation of root development. Annu. Rev. Plant Physiol. 35(1):223-242.

Furukawa, K., Y.Y. Yang, I. Honda, T. Yanagisawa, A. Sakurai, N. Takahashi, and Y. Kamiya. 1997. Effects of ethylene and gibberellins on the elongation of rice seedlings (Oryza sativa $\mathrm{L}$.). Biosci. Biotechnol. Biochem. 61(5):864-869.

Ganie, Z.A., M. Jugulam, and A.J. Jhala. 2017. Temperature influences efficacy, absorption, and translocation of 2,4-D or glyphosate in glyphosate-resistant and glyphosate-susceptible common ragweed (Ambrosia artemisiifolia) and giant ragweed (Ambrosia trifida). Weed Sci. 65(5):588-602.

Godar, A.S., V.K. Varanasi, S. Nakka, P.V. Prasad, C.R. Thompson, and J. Mithila. 2015. Physiological and molecular mechanisms of differential sensitivity of Palmer amaranth (Amaranthus palmeri) to mesotrione at varying growth temperatures. PLoS One 10(5):e0126731.

Hammer, A. 2001. Calculations. In: M.L. Gaston, P.S. Konjoian, L.A. Kunkle, and M.F. Wilt (eds.). Tips on regulating growth of floriculture crops. O.F.A. Serv., Inc., Columbus, OH.

Hayashi, T., R.D. Heins, A.C. Cameron, and W.H. Carlson. 2001. Ethephon influences flowering, height, and branching of several herbaceous perennials. Scientia Hort. 91(3-4):305-324.

Kaczperski, M.P., W.H. Carlson, and M.G. Karlsson. 1991. Growth and development of Petunia $x$ hybrids as a function of temperature and irradiance. J. Amer. Soc. Hort. Sci. 116(2):232-237.

Klein, I., S. Lavee, and Y. Ben-Tal. 1979. Effect of water vapor pressure on the thermal decomposition of 2-chloroethylphosphonic acid. Plant Physiol. 63(3):474-477.

Longstaff, B.C. 1988. A modelling study of the effects of temperature manipulation upon the control of Sitophilus oryzae (Coleoptera:
Curculionidae) by insecticide. J. Appl. Ecol. 25:163-175.

Lougheed, E.C. and E.W. Franklin. 1972. Effects of temperature on ethylene evolution from ethephon. Can. J. Plant Sci. 52(5):769-773.

McReynolds, R.D. and S.V. Kossuth. 1985. CEPA in liquid sulfuric acid increases oleoresin yields. South. J. Appl. For. 9(3):170-173.

McWhorter, C.G., T.N. Jordan, and G.D. Wills. 1980. Translocation of 14 C-glyphosate in soybeans (Glycine max) and johnsongrass (Sorghum halepense). Weed Sci. 28(1):113-118.

Miller, W.B., N.S. Mattson, X. Xie, D. Xu, C.J. Currey, K.L. Clemens, R.G. Lopez, M. Olrich, and E.S. Runkle. 2012. Ethephon substrate drenches inhibit stem extension of floriculture crops. HortScience 47:1312-1319.

Moccaldi, L. and E.S. Runkle. 2007. Modeling the effects of temperature and photosynthetic daily light integral on growth and flowering of Salvia splendens and Tagetes patula. J. Amer. Hort. Sci. 132:283-288.

Mueller, T.C., C.L. Main, M.A. Thompson, and L.E. Steckel. 2006. Comparison of glyphosate salts (isopropylamine, diammonium, and potassium) and calcium and magnesium concentrations on the control of various weeds. Weed Technol. 20:164-171.

Musgrave, A., M.B. Jackson, and E. Ling. 1972. Callitriche stem elongation is controlled by ethylene and gibberellin. Nat. New Biol. 238(81): 93-96.

Musgrave, A. and J. Walters. 1973. Ethylenestimulated growth and auxin ansport in Ranunculus sceleratus petioles. New Phytol. 72(4) 783-789.

Nalewaja, J.D. and R. Matysiak. 1993. Spray carrier salts affect herbicide toxicity to kochia (Kochia scoparia). Weed Technol. 7:154-158.

Rademacher, W. 2000. Growth retardants: Effects on gibberellin biosynthesis and other metabolic pathways. Annu. Rev. Plant Biol. 51(1):501531.

Ridge, I. and D.J. Osborne. 1969. Cell growth and cellulases: Regulation by ethylene and indole3 -acetic acid in shoots of Pisum sativum. Nature 223(5203):318-319.

Ridge, I. 1973. The control of cell shape and rate of cell expansion by ethylene: Effects on microfibril orientation and cell wall extensibility in etiolated peas. Acta Bot. Neerl. 22(2): 144-158.

Roberts, J.A., C.B. Schindler, and G.A. Tucker. 1984. Ethylene-promoted tomato flower abscission and the possible involvement of an inhibitor. Planta 160(2):159-163.

USDA. 2016. National Agricultural Statistics Service. Floriculture crops 2015 summary. 20 June 2018. <http://usda.mannlib.cornell.edu/usda/current/ FlorCrop/FlorCrop-04-26-2016.pdf>.

Voesenek, L.A.C.J. and C.W.P.M. Blom. 1989. Growth responses of Rumex species in relation to submergence and ethylene. Plant Cell Environ. 12(4):433-439.

Warner, H.L. and A.C. Leopold. 1969. Ethylene evolution from 2-chloroethylphosphonic acid. Plant Physiol. 44(1):156-158. 